\title{
POSTNATAL DEVELOPMENT OF THE CHOLECYSTOKININ-GASTRIN FAMILY OF PEPTIDES IN THE BRAIN AND GUT OF RAT
}

\author{
Michel Noyer, Ngoc Diem Buí, Monique Deschodt-Lanckman, Patrick Robberecht, \\ Marie-Claire Woussen, and Jean Christophe.
}

Department of Biochemistry and Nutrition, School of Medicine, Université Libre de Bruxelles, Boul evard de Waterloo 115, B-1000 Brussels, Belgium,

(Received in final form September 30, 1980)

\section{Summary}

The average levels of CCK-8- and CCK-1ike peptides present in aqueous and acidic extracts of the brain of the newborn rat were, respectively, 5.3 and $2.9 \mathrm{pmol} / \mathrm{g}$ wet weight. These low levels increased 20- and 10-fold, respectively, so as to attain, at 25-30 days post partum, values comparable to those found in adult brain. There was also a rapid deposition of CCK-gastrin-like peptides in the whole gut between day 20 post coitum and day 10 post partum, when maximal concentrations were attained. Later, less CCK-gastrin peptides than other gut components were accumulated during the progressive weaning of the young rats, so that the average concentrations of CCK-gastrinlike peptides were, at day 30 , similar to those observed in adult gut.

Cholecystokinin-pancreozymin (CCK), originally isolated from porcine jejunum as a triacontatri apeptide ( CCK-33) and a triacontanonapeptide (CCK-39) (1), shares with gastrin the same biologically active C-terminal pentapeptide amide sequence GLY-TRP-MET-ASP-PHE-NH . Like a number of other gut peptides, CCK is al so present in brain. Vanderhaeghen et al. described in 1975 the presence of a major brain peptide reacting with gastrin antiserum and having a mol ecular size smaller than gastrin 17 (2). This peptide was later identified as being CCK-8 (3-7). It now appears that CCK in different forms is present in bo th brain and gut, with CCK-8 and CCK-4-1 ike forms predominating over CCK-33 and CCK $-39(7,8)$. In particular, large amounts of CCK peptides are widely distributed in most brain regions (7) where they are synthesized (9) and stored in synaptic vesicles (10) from which they are released following depolarization with $\mathrm{K}^{+}$in the presence of $\mathrm{Ca}^{2+}(11)$. The present study documents the postnatal development pattern of CCK-gastrin-like peptides in brain and gut in the rat.

\section{Materials and methods}

\section{Animals.}

Wistar rats were obtained from our breeding colony. Foetuses were obtained by cesarean section from the mother after anaesthesia with ether. Their ages were determined from mating time. Birth dates of neonates were recorded 22 days after mating by twice-daily inspections of the animal house. Rats began to nibble at the standard chow of fered to the mothers when 15 to 18 days-old. No selection was made with regard to the sex up to 32 days of age. Young adult rats used for comparison were $120-150 \mathrm{~g}$ males.

Abbreviations : CCK-39, CCK-33, CCK -8, CCK -4 : C-terminal triacontanona-, triacontatria-, octa-, and tetrapeptide of cholecystokinin-pancreozymin. 


\section{Extraction procedure.}

Animals were weighed and killed by decapitation. The entire gut was excised from pylorus to rectum, slit open, washed, weighed, and immediately frozen in liquid nitrogen. The whole brain was resected without brain stem and cerebellum, and rapidly frozen in liquid nitrogen. Rats ranged in age from 20 days gestation to 90 days after birth. For foetuses and for neonates less than 4 days-old, guts and brains from 3 animals were pooled. Between 4 and 6 days, the tissues from 2 animals were pooled, and after 8 days of age, the organs were treated individually. CCK peptides were extracted by the sequential method of Rehfeld (7) as modified by Larsson and Rehfeld (12). The frozen tissues were subsequently dropped into boil ing distilled water for $10 \mathrm{~min}$ ( $10 \mathrm{ml} / 1-3 \mathrm{brains}$ and $10 \mathrm{ml} / 1-3$ guts, depending on the age). The tissue samples were then homogenized in a Potter homogenizer equipped with a Teflon pestle, and centrifuged for $30 \mathrm{~min}$ at $100,000 \times \mathrm{g}$. The supernat ants were collected and frozen at $-20^{\circ} \mathrm{C}$. The pellets were further extracted with $3 \mathrm{ml} 0.5 \mathrm{M}$ acetic acid. After $15 \mathrm{~min}$ at $20^{\circ} \mathrm{C}$, the pellets were homogenized and the homogenate was centrifuged for $30 \mathrm{~min}$ at $100,000 \times \mathrm{g}$. The acidic supernatants were neutral ized with ammonia and kept frozen at $-20^{\circ} \mathrm{C}$. It can be inferred from data in refs $(7,12)$ that this sequential extraction al lows the recovery of CCK -8 and CCK -4 in the aqueous extracts, and the desorption of langer molecular forms such as CCK-39, and CCK-33 from the acidified pellets.

\section{Radio immuno assay.}

The antiserum was originally raised in a rabbit against gastrin $1-(2-17)$ covalently coupled to bovine serum albumin by carbodiimide. The first bleeding, called $3737 \mathrm{~b}$, was originally used for gastrin radioimunoassays (13). Its I50human gastrin I-(1-17)/I50-CCK-8 ratio was as low as 0.0028 (Fig. 1). After boost injections of gastrin $I-(2-17)$ in the same rabbit, the capacity to recognize CCK-8 increased 60- fold. The characteristics of the less specific new antiserum $3737 \mathrm{f}$ (Fig. 1) indicate a binding capacity for all CCK and gastrin-1 ike peptides containing the $\mathrm{COOH}$-terminal pentapeptide amide cormon to CCK and gastrins. The 150 -human gastrin $1-(1-17) / 150-C C K-8$ ratio was now as high as 0.08 . This antibody bound CCK -8 and gastrin $1-(11-17)$ with equimol ar potency. It reacted more poorly with CCK -33 and caerulein. It had almost no affinity for CCK -4 and for the mid region of human gastrin I-(1-17), as shown with gastrin 1-(1-13). In the present study, the peptides in tissue extracts were measured with antiserum $3737 \mathrm{f}$ (except when stated otherwise), synthetic CCK-8 and pure natural porcine CCK-33 as standards, and $125 \mathrm{I}-\mathrm{gas}$ trin as tracer. Synthetic human gastrin $1-(1-17)$ was radioiodinated using the chloramine-T method (14). The monoiodinated form was separated on DEAE-Sephadex, according to Brown et al. (15). Bound and free tracer were separated with charcoal coated with human serum. In practice, $0.25 \mathrm{ml}$ of sample, $0.05 \mathrm{ml}$ of tracer containing $5,000 \mathrm{cpm}$ of $125 \mathrm{I}-\mathrm{g}$ astrin $\mathrm{I}-(1-17)$, and $0.3 \mathrm{ml}$ of antiserum solution in $0.1 \mathrm{M}$ phosphate buffer ( $\mathrm{pH} 7.4$ ) enriched with $1 \%$ bovine serum albumin were mixed and incubated for 2-3 days at $4^{\circ} \mathrm{C}$. Antibody-bound and unbound tracer were separated by centrifugation after addition of $20 \mathrm{mg}$ of charcoal. The extracts were assayed in triplicate and the results expressed in pmoles of CCK- 8 equivalents/g wet weight of original tissue for the aqueous extracts, and in pmoles of CCK-33 equivalents for the acidic extracts.

\section{Peptides.}

Synthet IC CCK -8 (SQ 19844) was a gift from Dr. S.J. Lucania (Squibb Institute for Medical Research, Princeton, N.J., U.S.A.). Natural cholecystokininpancreozymin ( $99 \%$ pure CCK-33) was generously suppl ied by Dr. V. Mutt (Gastrointestinal Hormone Research Unit of the Karol inska Institutet, Stockholm, Sweden). Caerulein was a gift from Dr. de Castiglione (Farmitalia, Montedison, Milano, Italy). Human gastrin $\mathrm{I}-(1-17)$ desulfated, human gastrin $\mathrm{I}-(2-17)$ desulfated, human gastrin $1-(1-13)$ tridecapeptide desulfated, and heptagastrin I- $(11-17)$-heptapeptide desulfated were, synthesized by Dr. Morley (Imperi al 
Chemicals (Dielsdorf, Switzerland). $\mathrm{Na}^{125} \mathrm{I}(16.45 \mathrm{mCi} / \mathrm{\mu g}$ iodine) was supplied by the Radiochemical Centre (Amersham, England). All other reagents were of the highest grade available.

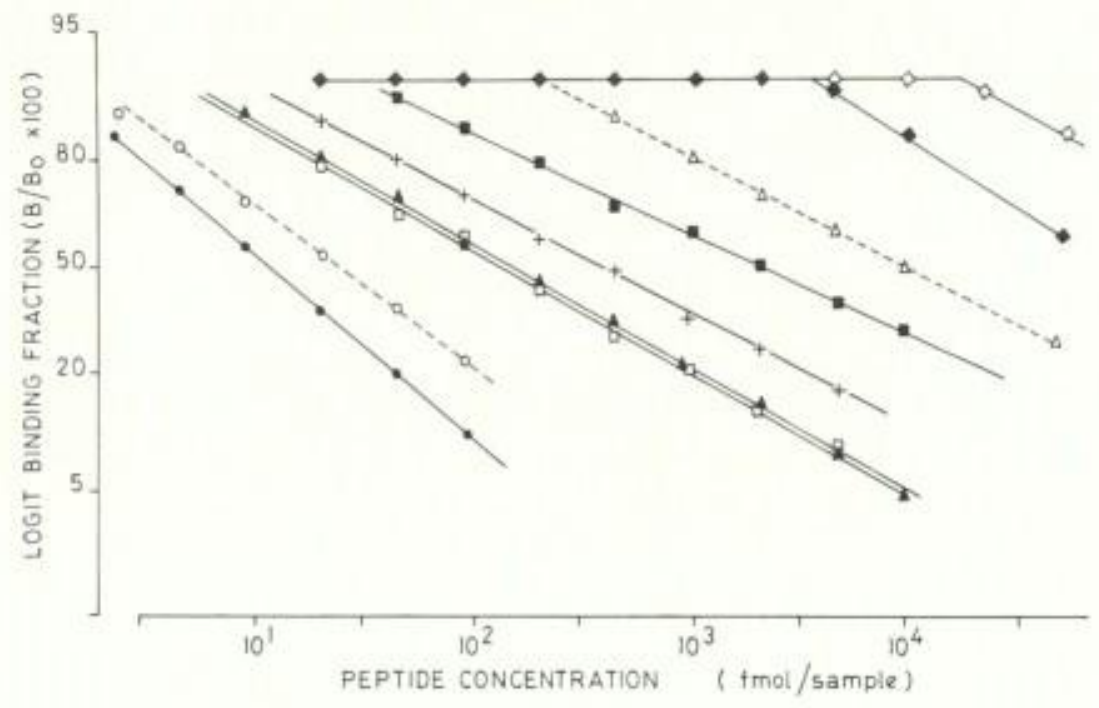

FIG. 1

Standard calibration curves for imunoreactive peptides of the CCKgastrin family. The following standards, with respect to displacement of mono iodinated 125I human gastrin I- $(1-17)$ from antiserum $3737 \mathrm{~b}$ $(--)$ and antiserum 3737 f $(-)$ were used : human gastrin $I-(1-17)$ desulfated : $\bullet$ and 0 ; CCK $-8: \Delta$ and $\Delta$; human heptagastrin $1-(11-17)-$ heptapeptide desulfated : a ; CCK-33: + ; caerulein - ; human gastrin $1-(1-13)$ tridecapeptide desulfated : $\bullet$; CCK $-4: \diamond$. The final antiserum dilution was $1: 40000 ; B_{0}$ around $50 \% ; 5000 \mathrm{cpm}$ of monoiodinated human gastrin I was added per test tube.

\section{Results}

Levels of CCK-like peptides in brain during development.

CCK-1ike peptides were al ready present at birth (Fig. 2 ) in aqueous

extracts : $5.3+0.7$ pmoles of CCK -8 like peptides $/ 9$ wet weight as well as in acidic extracts ${ }^{-}: 2.9+0.3$ pmoles of $C C K-33$ equivalents $/ g$ wet weight (means \pm S.D., $n=4$ ). These levels increased continuously and markedly from birth to the 30th day ( $\mathrm{Fig} .2$ ) when they reached the adul $\mathrm{t}$ values of $67.7 \pm 3.4$ pmoles of CCK -8 equivalents/g wet weight for aqueous extracts, and $24.2 \mp 1.5$ pmoles of CCK-33 equivalents $/ g$ wet weight for acidic extracts (mean $\pm S . \bar{D} ., n=5$ ). In both aqueous and acidic extracts, half-maximal levels of CčK peptides were attained around the 15 th day. There was a striking parallel ism in the accumulation pattern of CCK peptides in aqueous and acidic extracts, except in brains of animals younger than 4 days, where the large molecular forms in acidic extracts appeared to be somewhat more abundant : at one day of age, for instance, the concentration in acidic extracts represented $12 \%$ of adult levels while the concentration in aqueous extracts represented $8 \%$ of adult levels.

Levels of CCK-gastrin peptides in gut during development.

Radio immuno assay measurements in gut reflected the levels of both CCKand gastrin-1ike peptides (see Discussion). Twenty days post coitum (Fig. 3, 


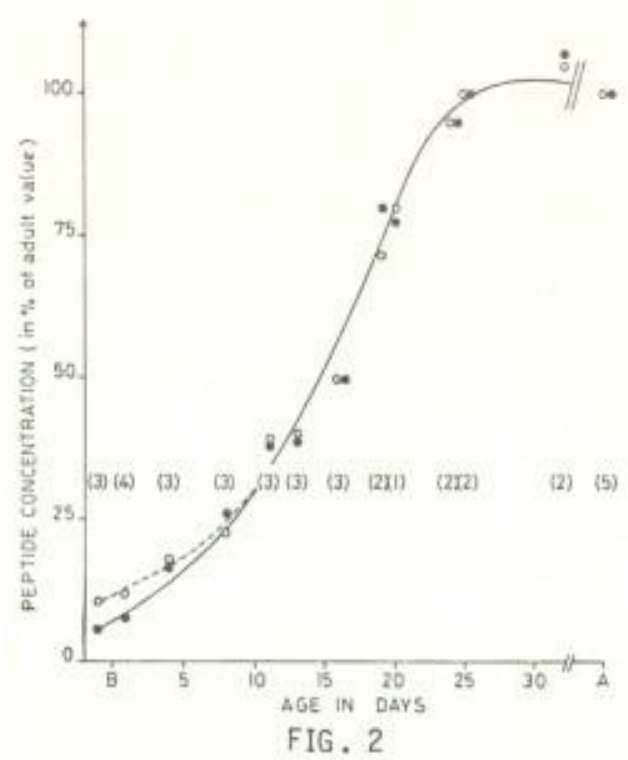

Developmental changes of CCK peptides in aqueous and acidic extracts of rat brain. The resul ts were calculated in CCK -8 equivalent $/ g$ wet weight for aqueous extracts $(\bullet-)$ ) and in CCK-33 equival ents $/ g$ wet weight for acidic extracts $(0-0)$ and were expressed in percent of adult values. The number of brain extracts investigated is ment ioned under brackets. For animals younger than 6 days, two or more brains were pooled for a single determination. $B=$ birth. $A=120-$ to $150-g$ male adults.

Panel A), the levels of CCK-gastrin peptides in aqueous extracts were 4-times higher and those of CCK-like peptides in acidic extracts were similar to those observed in adul t gut, when expressed per $g$ wet weight of tissue. These concentrations increased in both aqueous and acidic extracts from birth to day 4 post partum. Maximal values remained relatively constant until the 14 th day and then decreased rapidly so that adult levels were attained around the 30 th day in aqueous extracts, and the 20th day in acidic extracts. The average concentrations of CCK-gastrin peptides finally attained in the entire gut at day 30 were, on a molar basis, similar to those present in the adult gut. The adul t concentrations were $73.4 \pm 15.1$ pmoles $/ g$ wet weight for aqueous extracts and $20.4 \pm 3.7$ pmoles $/ 9$ wet weight for acidic extracts (mean $+S . D ., n=5$ ). The accumullation pattern of CCK-gastrin peptides in gut is made more obvious in Fig. 3, Panel B, where data are expressed per whole gut.

\section{Discussion}

1. Val idity of the radioimunoassays.

Consinering the antisera utilized, it is clear that peptides of the CCK family were only measured accurately in the absence of gastrin(s). In addition, the present data took only partially into account the heterogeneity of molecular forms (7) and species differences. The estimation of the absolute concentrations of the different CCK peptides in rat tissues must await their purification, characterization, and subsequent use as appropriate rat standards. In prel iminary experiments, we observed that rat brain CCK-8 was indistinguishable from porcine CCK -8 on the basis of its charge, size, immunological, and biological properties. Another fraction separated by DEAE-cellulose chromatography from rat brain was more acidic than porcine CCK -33 but cochromatographed with porcine CCK -33 on Biogel $P-2$, yielded CCK -8 upon trypsin digestion, and 
might well be rat CCK. A similar species specificity has al ready been reported in the $\mathrm{NH}_{2}$-terminal portion of porcine, monkey, and dog CCK (16) and of porcine, human, and rodent gastrins $(17,18)$.

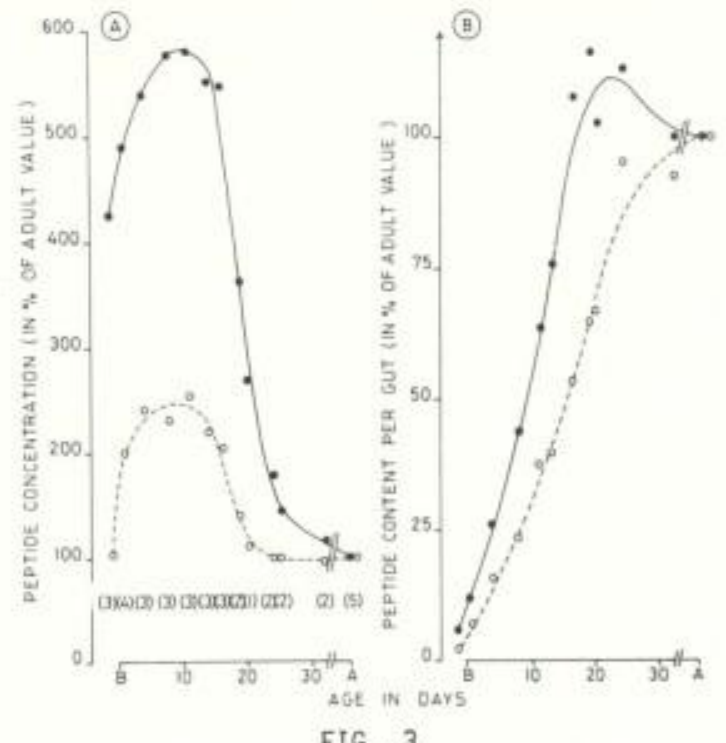

FIG. 3

Developmental changes of CCK-gastrin peptides in aqueous and acidic extracts of rat gut. The results were cal culated in CCK-8 equivalents $/ g$ wet weight for aqueous extracts $(\bullet-\bullet)$ and in CCK -33 equivalents $/ g$ wet weight for acidic extracts $(0-0)$, and were expressed in percent of adul $t$ values. The number of gut extracts investigated is mentioned in Panel A. For animals younger than 6 days, two or more guts were pooled for a single determination. $B=$ birth. $A=120-$ to 150 -g male adul ts.

In brain, CCK in different molecular forms is known to be widely distributed in the neurons of most brain regions, except the cerebellum, epithal amus, and pituitary $(7,9,12,19,20)$ and, so far, only vasoactive intestinal peptide has also been localized to neocortical regions (21). In the present study, the aver age concentration of 68 pmoles of CCK-8 equivalents $/ g$ wet weight found in aqueous extracts of whole adult rat brains agreed with the figure of $50-150$ pmoles/g rat brain reported by Dockray (3). These levels of brain CCK exceed those of any other known brain peptide (7). A significant contribution of CCK-4 to this value was most unlikely, considering the very low affinity for CCK-4 of the antiserum used (Fig. 1). The value of 24 pmoles/g wet weight CCK -33 equivalents found here in acidic extracts is indicative only since acidic extracts are heterogeneous (12). Furthermore, we did not dispose of rat standards in adequate amounts. True gastrin did not interfere with the present radioimunoassays in brain, since it is located, in small amount only, in the hypothal amus, infundibulum, and the lower part of the medull a oblong ata (9) while being a major form in the hypophysis (22) and in the vagal nerves (23). In adul $t$ gut, the concentrations of CCK-gastrin peptides were comparable to those found in brain. Endocrine cells rich, respectively, in CCK (I cells), CCK-4 (TG cells), and gastrin-34 (GI or Ga cells) are reported to coexist in the small intestine while CCK- and gastrin-nerves are numerous in the large intestine and distal ileon $(12,24,25)$. In the present study, where the entire gut was taken, it is clear that CCK-gastrin peptides originating from both endocrine cells and nerves were extracted. CCK -4 could not be detected (Fig.1) but menters of the gastrin family, that are easily solubilized with boiling 
water at neutral pH (26), were able to interfere with the measurement of CCK-8-1ike peptides in aqueous extracts (see below).

Developmental pattern of CCK-like peptides in rat brain and gut.

In brain, peptide accumulation was made especially obvious by representing the data as \% of adult values (Fig. 2). The small (in aqueous extracts) and large (in acidic extracts) molecular forms of CCK present at birth increased 20 - and 10-fold, respectively, to attain adult levels at 4 weeks after birth. This developmental pattern covered the neonatal as well as the late suckling period. The maximal rate of increment was at 0-6 days of age, a period marked by neuronal multiplication. Adult concentrations were reached at 20 days, i.e. when the period of proliferation of neuronal processes, myel ination of axons, and multiplication of ol igodendroglia was mostly over (27).

This considerable accumulation of CCK peptides in the neurons of the developing rat brain probably reflected increased rates of peptide synthesis and/or low peptidase activity. In vivo biosynthesis of CCK peptides indeed occurs in rat cerebral cortex (9), and the large forms may represent biosynthetic precursors of CCK -8 and CCK -4 , since enzymes converting CCK -33 into CCK -12 and CCK -8 are present in brain $(16,28)$. It is of interest to note that the ratio of large to small CCK peptides was constant throughout post-natal devel opment, except for the period around birth when the large molecular forms were more abundant. It is terpting to speculate that the proteolytic cleavage of precursors was less active during this period.

The present pattern of accumulation of CCK peptides differred from that of other brain-gut peptides. We have shown $(29)$ that the low level of VIP present at birth in rat brain ( 17 pmoles/g wet weight) remains constant during the first two week 5 and then doubles progressively to reach at 20 days a value comparable to that found in adult animals. For substance $P$ al so, a slow rise during the first two weeks of life is followed by larger increments between day 14 and 28 post-partum (30).

In gut, the pattern of accumulation of CCK-gastrin peptides differred markedly from that observed in brain. Maximal concentrations were observed in neonates, between the 4th and the 15th day post-partum, and then decreased to reach adult value around day 20-30 (Fig. 3). Larsson, using histochemical methods $(25,31)$, has described peak frequencies of gastrin cells and CCK(I) cells, respectively between day $1-4$ and $10-15$, in the $r$ at duodenum, which are followed by a progressive decrease in frequency between day 15 and day 18 , i.e. When the smali intestine of the rat shows a striking increase in the rate of cellular proliferation (32). Since the timing of development of CCK-gastrin peptides preceded that of rapid growth of the intestines (Fig. 3 ), it is conceivable that the release of more gastrointestinal hormones, at the onset of the weaning period, and the development of CCK $-\mathrm{g}$ astrin nerves, contributed to this cell proliferation in the intestinal mucosa (33). It is noteworthy that the aver age concentrations of CCK-gastrin peptides in adult gut were comparable to those observed in brain.

In order to examine the contribution of gastrin to the present devel opmental curves, we used antiserum $3737 \mathrm{~b}$ with which CCK-8 reacted very poorly (Fig. 1). Based on the assumption that $r$ at gastrin(s) behave as human gastrin I- $(1-17)$, the gastrin contents in aqueous extracts of guts from 4 days-old, 11 days-old and adult rats were always low : $2.2,4.8$, and 12.6 pmoles gastrin $\mathrm{I}-(1-17)$ equivalents, respectively, per total gut. With the less specific antiserum $3737 \mathrm{f}$, these gastrin concentrations should correspond to 18,63 , and 240 pmoles of CCK-8 equivalents, as derived from standard calibration curves (Fig. 1). Since the corresponding total CCK-8-1 ike concentrations were in fact 126,339 , and 839 pmoles, it appears that true gastrin(s) contributed only $14 \%$ of the total at 4 days, $19 \%$ at 11 days, and $29 \%$ in the adult state. It $c$ an thus be concluded that the accumulation pattern between days 4 and 11 in aqueous extracts (Fig. 3) was mainly due to CCK-8-1ike peptides. This accumulation pattern of CCK-gastrin peptides in gut differred from that of VIP (34) and substance $P(30)$ whose contents in the small intestine increase 
mainly during the third weak of life,

\section{Acknowledgments}

This work was supported by Grant RO-IAM-17010 from the National Institutes of Heal th (U.S.A.) and Grant 3014 from I.R.S.I.A.-JANSSEN (Belgium).

\section{References}

1. V. MUTT and E. JORPES, Eur. J. Biochem. 6, 156-162 (1968).

2. J.J. VANDERHAEGHEN, J.C. SIGNEAU and W. GEPTS, Nature 257, 604-605 (1975).

3. G.J. DOCKRAY, Nature (London) 264, 568-570 (1976).

4. G.J. DOCKRAY, R.A. GREGORY, J.B. HUTCHISON, J.I. HARRIS and M.J. RUNSWICK, Nature (London) 274, 711-713 (1978).

5. J.E. MLLLER, E. STRAUS and R.S. YALOW, Proc. Natl. Acad. Sci. (U.S.A.) $74,3035-3037$ (1977).

6. P. ROBRERECHT, M. DESCHODT-LANOKMAN and J.J. VANDERHAEGHEN, Proc. Natl. Acad. Sci. (U.S.A.) 75, 524-528 (1978).

7. J.F. REHFELD, J. BioT. Chem. $253,4022-4030$ (1978).

8. J.F. REHFELD, J. Biol. Chem. 253, $4016-4021$ (1978).

9. J.F. REHFELD, N. GOLTERMANN, L.-I. LARSSON, P.M. EMSON and C.M. LEE, Federation Proc. 38, 2325-2329 (1979).

10. M. PINGET, E. STRAIUS and R.S. YALOW, Proc. Natl. Acad. Sci. (U.S.A.) 75, 6324-6326 (1978).

11. M. PINGET, E. STRAUS and R.S. YALOW, Life SCI. 25, 339-342 (1979).

12. L. -1 . LARSSON and J.F. REHFELD, Brain Res. 165, 201-218 (1979).

13. M.C. WOUSSEN-COLLE, G. WILLEMS and J. DE GRAEF, Digestion $15,322-328$ (1977).

14. P.C. GANGULI and W.M. HUNTER, in Radioimunoassay Methods (eds. Kirkhan and Hunter) pp. 54-60, Churchill Livingstone, Edinburgh (1971).

15. T.R. BROWN, N. BAGCHI, R.E. MACK, E. BOOTH and D.P. JONES, Clin. Chim. Act a $67,321-323(1976)$.

16. E. STRAUS, A. MALESCI and R.S. YALOW, Proc. Nat1. Acad. Sci. (U.S.A.) $75,5711-5714$ (1978).

17. G.J. DOCKRAY, Gastroenterol. 72, 344-358 (1977).

18. A.L. HOL.MQUIST, J.H. WALSH and E.J. FELDMAN, Gastroenterol. 72, 1071 (1977).

19. R.B. INNIS, F.M.A. CORREA, G.R. UHL, B. SCHNEIDER and S.H. SNYDER, Proc. Nat1. Acad. Sci. (U.S.A.) 76, 521-525 (1979).

20. J.J. VANDERHAEghEN, F. LOTSTRA, J. DE MEY and C. GILles, Proc. Nat1. Acad. Sci. (U.S.A.) 77, 1190-1194 (1980).

21. K. FUXE, T. HOKFEL T, S. SAID and V. MUTT, Neurosc. Lett. 5, 241-246 (1977).

22. J.F. REHFELD, Nature (London) 271, 771-773 (1978).

23. K. UVNAS-WALLENSTEN, J.F. REHFELD, L.-I. LARSSON and B. UVNAS, Proc. Nat1. ACad. Sci. (U.S.A.) 74, 5707-5710 (1977).

24. R. BUFFA, E. SOLCIA and V.L.M. GO, Gas troenterol. 70, 528-532 (1976).

25. L. - I. LARSSON, His tochem. 54, 133-142 (1977).

25. R.A. GREGORY and H.J. TRACY, Gut 5, 103-117 (1964).

27. A.N. DAVISON and J. DOBBING, in Appl led Neurochemistry (eds. A.N. Davison and J. Dobbing) pp. 253-286, Blackwell Scientific Publications, Oxford, Edinburgh ( 1968 ).

28. A. MALESCI, E. STRAUS and R.S. YALOW, Proc. Nat1. Acad. Sci. (U.S.A.) 77, 597-599 (1980).

29. P. ROBBERECHT, M. DESCHODT-LANCKMAN, P. DE NEEF and J. CHRISTOPHE, Life Sci. 25, 1001-1008 (1979).

30. R.F.T. GILBERT and P.C. EMSON, Brain Res. 171, 166-170 (1979).

31. L.-I. LARSSON and L.M. JđRGENSEN, Cell. Tiss. Res. 194, 79-102 (1978).

32. J.J. HERBST and P. SUNSHINE, Pediat. Res. 3, 27-33 (1969).

33. L. LiCHTENBERGER and L.R. JOHNSON, Am. J. Physiol. 227, 390-395 (1974).

34. M. LABURTHE, D. BATAILLE and G. ROSSEL IN, ACt a Endocrino1. 84, 588-599 (1977). 